\title{
MANAGEMENT EVENT OF SPORT TOURISM (DRAGON BOAT RACE) IN LAKE TOBA NORTH SUMATERA
}

\author{
Albert Wolter Aridan Tangkudung ${ }^{1}$, James Tangkudung ${ }^{2}$ \\ Universitas Negeri Jakarta ${ }^{1,2}$ \\ albert.wolter@unj.ac.id
}

\begin{abstract}
The purpose of this study was to determine the management system for implementation of Solu Bolon sport tourism event and impact after the implementation of the event. The research method used was mis methods (qualitative and quantitative). The sample consisted of 23 informants. Results in this study includes legal and policy got a percentage of $86.14 \%$, goal got $79.78 \%$ and, target got $73.55 \%$. That participants got a percentage of $81.25 \%$, management got a percentage of $79.89 \%$, financing got a percentage of $84.30 \%$, committees got a percentage of $80.87 \%$, nature got a percentage of $86.96 \%$ and, culture got a percentage of $87.50 \%$. rule of the game got a percentage of $85.14 \%$, implementation events got a percentage of $81.88 \%$ and supervision obtained a percentage of $84.78 \%$. that focus on events that attract people only get a percentage of $67.39 \%$, economic benefits $78.62 \%$, promotion $88.04 \%$ and visitors $63.04 \%$. Based on the research results, it can be concluded that the management event of sport tourism in Lake Toba is in a good category because in accordance with the planning that has been made and can achieve the desired target. It can be concluded that the sport tourism event can have a positive effect on economic growth with the large number of local and domestic visitors seeing this event, while the development of tourism potential after the event needs to be re-studied because it has not had a good impact.
\end{abstract}

Keywords: Management Event, Sport Tourism, Benefit Economy

Accepted: 26th of November 2021

Correspondence author: Albert Wolter Aridan Tangkudung, Universitas Negeri Jakarta, Indonesia. E-Mail: albert.wolter@unj.ac.id

DOI http://dx.doi.org/10.31851/hon.v5i1.6493

\section{(i) (2)}

Jurnal Halaman Olahraga Nusantara licensed under a Creative Commons Attribution-ShareAlike 4.0 International License

\section{INTRODUCTION}

Sport tourism is part of the tourism industry with a very fast development in various regions in Indonesia. One of the fastest growing tourism industries is travel related to sports. Other destination branding features such as improving safety aspects and more visible on-site branding are contingent on investment and leveraging strategies from both public and private entities (Hemmonsbey and Tichaawa 2020). That a small-scale sports event portfolio consistent with a community's infrastructure and human and cultural capital may be a viable form of sustainable tourism development (Gibson, Kaplanidou, and Kang 2012). Many entrepreneurs seized a business opportunity mainly for personal reasons related to enjoying a good lifestyle, 
being in an attractive natural and human environment, and seeking autonomy at work (Fadda 2020). All forms of active and passive involvement of all stakeholders in sports activities strongly support the commercial / business value which requires traveling far from home to the destination. There are several categories that are common in sports tourism activities, namely watching sports events, visiting tourist places / objects, participating / taking an active role in activities (Masjhoer and Tyas 2020). The sport management literature by adding sport-specific factors influencing location decision-making in the sport industry and suggest a new framework for these factors (Happ, Schnitzer, and Peters 2021).

Revealed the multi-dimensional nature of perceived social impacts and contributed to a better understanding of how local residents view the impacts associated with a large-scale sport tourism event (Kim et al. 2015). Organizing sport tourism events by combining two sports and tourism activities is expected to have a positive impact on regional progress. This event must be carried out on an ongoing basis so that the program being implemented can have a significant impact on society. Local and non-local participants evaluate their event experiences differently and provide practical implications for event organizers (An, Harada, and Sato 2020). In Indonesia, this activity is being carried out in several provinces that have tourism potential to attract tourist visits and promote local culture. Sport tourism is expected to be one of the key elements to stimulate rural areas by utilizing their potential natural resources (Yamashita and Takata 2020). Organizing sporting events in general has contributed to the level of local income and local residents (Marsudi, Imam, Tandiyo, 2016). The results show that this contribution is higher in those economies where tourism accounts for a higher share of gross domestic product (GDP) (Ivanov and Webster 2013).

Sport and tourism are global social and economic phenomena that increasingly demonstrate a convergence of business, planning and management interests (Buning 2019). The development and management of tourism and sports objects requires cooperation between the government and the private sector. Management and development of clear and structured tourism objects will be able to build and advance the tourism industry, especially sports tourism which will have an impact on various groups such as local and foreign tourists. Foundation for a more nuanced and targeted activity sports tourism strategy, which might have implications for how activity sports tourism may contribute to health and well-being and local economic 
development to better inform tourism planning and policy (Downward, Rasciute, and Muniz 2020). Increasing tourism destinations and investment, making tourism a key factor in export revenue, job creation, business development and infrastructure (Kemenpar 2016).

There also remains much potential for sports administrators to harness the interests of non-local residents as consumers of sport. Sports may, for example, moderate the spatial travel patterns of international tourists who may be attracted to the entertainment and cultural values of live sport, much to the benefit of host cities. Clearly, there are many unanswered questions that arise out of a consideration of the relationship between sport and tourism. The sport tourism program has become one of the leading programs to increase the attractiveness of tourists regarding travel and sports which include (tourism objects, participation in sports activities, or as a spectator of a competition). Strategic guidelines to improve the teaching of tourism withing the secondary education curriculum that could contribute to improve the touristic competitiveness of the country (Coll Ramis 2020). Spectator sporting events in sport tourism and a framework by which tourism can begin to assess its contributions to the global carbon footprint (Cooper 2020).

\section{METHOD}

The method used in this research is mixed methods (qualitative and quantitative). The data for this study were qualitative and quantitative collected from 23 informants and conducted for 2 months in 2019. Participant observation involving practical sampling and informal interviews was applied throughout this research. Data collection in the form of observations, questionnaires and, interviews. Observations are used in the implementation of sport tourism to determine the empirical conditions. The questionnaire is a number of written questions that are used to obtain information from respondents about the focus of the problem that can reveal the problems under study. Interview is used to obtain information about the research objectives by means of question and answer.

\section{RESULTS AND DISCUSSION}

Solu Bolon is one of the event Sport Tourism programs from Lake Toba North Sumatera government. This program was created to promote Lake Toba tourism, preserve the culture that depicts the ancient means of transportation, and increase visitors. The 
implementation of the Solu Bolon event is expected to have an impact on increasing economic benefits for the community. The results of this study will be shown below:

\section{Policy, Goal and target}

Evaluation context will discuss the law, purpose and targets. Tourism was decided to be the leading. The Ministry of Sports and Ministry of Tourism support the development of industrial sports and tourism sports. The context evaluation will explain the environmental needs, namely the Solu Bolon event policy which includes the vision, mission, goals and objectives. Based on this explanation, there are three sub-focus of context: 1) Legal and, Policy; 2) Goal; 3) Target. The results obtained can be seen in Table 1. as follows:

Table 1. Policy, Goal and Target

\begin{tabular}{cccc}
\hline Variable & \multicolumn{3}{c}{ Value } \\
& $\begin{array}{c}\text { Legal and } \\
\text { Policy }\end{array}$ & Goal & Target \\
\hline $\begin{array}{c}\text { Evaluasi } \\
\text { Context } \mathrm{n}=23 \\
\text { Percentage }\end{array}$ & 317 & 367 & 203 \\
\hline
\end{tabular}

Based on a questionnaire by 23 respondents, it was stated that legal and policy got a percentage of $86.14 \%$, Goal got $79.78 \%$ and, target got $73.55 \%$. Based on the results of observations on the implementation of Solu Bolon event based on the 2005 National Sports System Law concerning recreational sports. This event was held at Putri Lopian Beach, Lake Toba. Dragon boat race category, there is Lake Toba natural tourism. Solu bolon describes the elite means of transportation used in ancient times. Meanwhile, the results of interviews from several sources obtained the following data:

"The implementation of the Solu Bolon competition has gone well because there is a legal basis and supporting policies. This policy must be explained again through socialization involving the government and society so that the goals and targets can be known by the public" (Samosir City Youth Sports Culture Office).

"Solu Bolon is a sport tourism event held in tourist attractions and can create a different sports atmosphere. The government cares through sport tourism events to create economic and industrial opportunities for the community. It can be seen that every area that has tourism potential can be used as a place for Sport Tourism events" (Head of Youth, Sports and Tourism, Samosir City). 
"PODSI (Indonesian Rowboat Association) as the implementer always supports all government policies through the programs provided by the Samosir City government. This provides an opportunity for the community to participate in and contribute to the implementation of the event" (Chairman of the Rowboat Sports Committee of the City Samosir).

The implementation of the Solu Bolon event must have goals that focus on the expected success. Policy, goal and target as a whole there is a match between the planned program and the results achieved in the event. However, from the results of observations the expected objectives had not been achieved because overall participants only came from North Sumatra and Aceh Provinces. Unlike other events where participants can come from outside the province.

\section{Event Supported}

At this stage, identification of the conditions and support of the resources owned in the 2019 Solu Bolon event was carried out. Based on the focus of the problems identified, the evaluation of inputs includes: participants, management, financing, committee nature and culture. The results obtained from the input evaluation are shown in Table 2 below:

Table 2. Event Supported

\begin{tabular}{ccccccc}
\hline Variable & Participants & Managements & Financing & Committee & Nature & Culture \\
\hline $\begin{array}{c}\text { Evaluasi } \\
\text { Context } \mathrm{n}=\end{array}$ & 299 & 441 & 698 & 744 & 240 & 322 \\
23 & & & & & & \\
Percentage & $81,25 \%$ & $79,89 \%$ & $84,30 \%$ & $80,87 \%$ & $86,96 \%$ & $87,50 \%$ \\
\hline
\end{tabular}

The results of research involving 23 respondents stated that participants got a percentage of $81.25 \%$, management got a percentage of $79.89 \%$, financing got a percentage of $84.30 \%$, committees got a percentage of $80.87 \%$, nature got a percentage of $86.96 \%$ and, culture got a percentage of $87.50 \%$. Based on the results of observations, there were 21 teams who participated in the Solu Bolon event in the senior category. The following will display the names of the participating teams:

Table 3. Team Participants Solu Bolon

\begin{tabular}{lccc}
\hline \multirow{2}{*}{ Team } & \multicolumn{2}{c}{ Category } & \multirow{2}{*}{ Total Participants } \\
\cline { 2 - 3 } & Junior & Senior & \\
\hline Dayung Yonif 8 Marinir Brandan & & Upper 20 & 12 \\
Lobster Dragon Palipi & Upper 20 & 12 \\
\hline
\end{tabular}


HALAMAN - Jendral A. Yani Street Lorong Gotong Royong 9/10 Ulu OLAHRAGA Palembang South Sumatera

\begin{tabular}{lccc}
\hline \multirow{2}{*}{ Team } & \multicolumn{2}{c}{ Category } & \multirow{2}{*}{ Total Participants } \\
\cline { 2 - 3 } & Junior & Senior & \\
\hline Porhut Lontung & & Upper 20 & 13 \\
Pandulangan Sianjur Mulamula 5 & & Upper 20 & 12 \\
Dayung SMA negeri 1 Palipi & Under 18 & & 13 \\
CNN Sport Palipi & Under 18 & & 13 \\
Martoba Solu Bolon Club & & Upper 20 & 12 \\
Tobasa I & & Upper 20 & 12 \\
Tobasa II & Under 18 & & 12 \\
Tim Sitiotio Expres & & Upper 20 & 13 \\
Baktimas Humbahas & & Upper 20 & 13 \\
Popsir II & & Upper 20 & 13 \\
Marlumba & Under 18 & & 13 \\
Dayung junior Samosir & Under 18 & & 13 \\
Podsi kabupaten Bekasi & Under 18 & & 13 \\
Partao Lumban Suhisuhi Torupan & & Upper 20 & 13 \\
Tim Ambarita & & Upper 20 & 12 \\
Simeuleu Aceh & Under 18 & & 13 \\
Dayung Lugahon & & Upper 20 & 13 \\
Ogung Star & & Upper 20 & 13 \\
\hline
\end{tabular}

In addition to questionnaire data and observations, researchers obtained interview data from sources to strengthen research findings. The results of the interviews obtained from three sources are as follows:

"Participants who took part in the Solu Bolon competition came from the provinces of North Sumatra, Aceh and West Java. There are teams that take part in the competition that make a selection to get the best athletes and win the championship. There are also participants who come from the Marines" (Samosir City Youth Sports Culture Office).

"Participants who take part in the Solu Bolon event get information from social media and websites from the 2019 Horas Samosir Fiesta (HSF) series of events. Participant registration is also easy by sending team names and members via the website" (Team Simeuleu Aceh).

"Management can run the Solu Bolon event well because many parties support, for example: health and safety. The committee also prepared rowboat equipment well even though there were only 6 pieces. Nature and Culture Samosir City has its own characteristics based on history and folklore so that it becomes an appeal to the participants" (Team Podsi Bekasi).

"The committee obtains financing from the Samosir City government. Financing provided based on local government budgets to support the Solu Bolon event. The committee assigned comes from the Department of Culture, Youth and Sports in collaboration with the PODSI Indonesian Rowboat Association" (Chairman of PODSI Samosir City). 
The success of the event supported can be said to be appropriate based on the data obtained from questionnaires, observations and interviews. Then it can be decided that the input evaluation in supporting Solu Bolon event is in accordance with the expected criteria. However, there is something that needs to be improved for the next event in connection with rowboat facilities only amounting to 6 pieces.

\section{Implementation Event}

The evaluation at this stage will discuss the rules for rowing competitions and the implementation of the Solu Bolon event in 2019. At this stage, we will discuss the processes carried out during the race. There are three focuses, namely: 1) rowboat competition rules, 2) implementation and, 3) supervision. The results of the data that have been obtained from the implementation of the Solu Bolon event can be presented in table $\mathbf{4}$ as follows:

Table 4. Implementation Event

\begin{tabular}{cccc}
\hline Variable & $\begin{array}{c}\text { Rule of } \\
\text { the Game }\end{array}$ & $\begin{array}{c}\text { Implementation } \\
\text { Event }\end{array}$ & Supervision \\
\hline $\begin{array}{c}\text { Evaluasi } \\
\text { Process } n= \\
23\end{array}$ & 235 & 226 & 156 \\
\begin{tabular}{c} 
Percentage \\
\hline
\end{tabular} & $85,14 \%$ & $81,88 \%$ & $84,78 \%$ \\
\hline
\end{tabular}

Based on the results of filling out the questionnaire by 23 respondents, it was stated that rule of the game got a percentage of $85.14 \%$, implementation events got a percentage of $81.88 \%$ and supervision obtained a percentage of $84.78 \%$. In addition to the questionnaire data, observations about the competition rules were also obtained in table 5 below:

Table 5. Rule of The Game

\begin{tabular}{|c|c|c|}
\hline Participants & Rule of The Game & Equipments \\
\hline 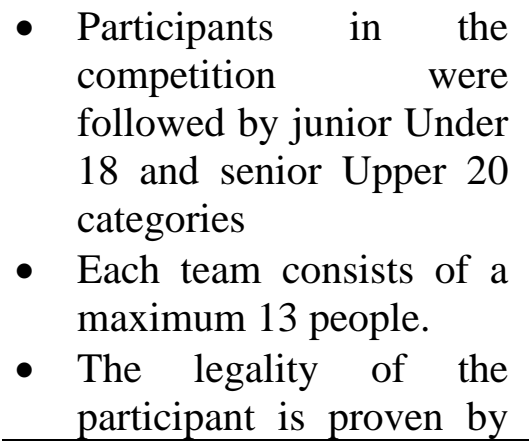 & 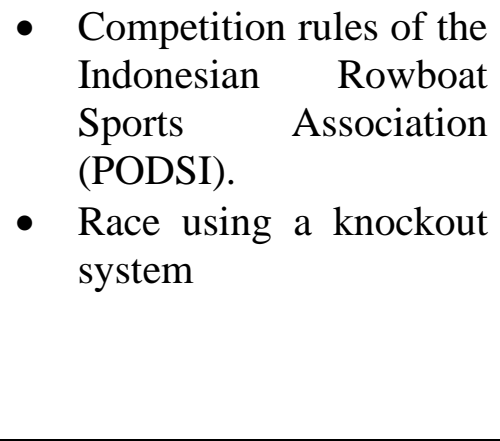 & $\begin{array}{l}\text { - The committee prepares } \\
\text { rowboats and paddles } \\
\text { - The length of the track } \\
\text { on Lake Toba is } 850 \\
\text { meters. }\end{array}$ \\
\hline
\end{tabular}




\begin{tabular}{lll}
\hline \hline \multicolumn{1}{c}{ Participants } & Rule of The Game & Equipments \\
\hline the identity sent during & & \\
registration &
\end{tabular}

In addition to the data above, the results of interviews were also obtained to support the results of this study. Based on the results of the interview, it will be explained as follows:

"Registration for the Solu Bolon event is according to the procedure set by the committee. All participants must have the identification card used during registration. Each team may only register a maximum of 13 athletes. Implementation of the Solu Bolon event, the committee coordinates with the government so that the implementation will be carried out as expected. All preparations and equipment used during the race are also prepared before the race starts. The committee also prepares a resque and security team to ensure the safety of all participants and committee members" (Chairman of the committee).

"The rules for rowing boat sports are in accordance with the regulations set by the PODSI organization. The competition is only for 3 days from 7 to 9 November 2019. The number of teams participating in the competition is only 21 so that the committee applies a knockout system for each race, only the 1st to 3th ranks are taken, on the second day there are 12 teams that take part in the next round. Apart from that, the committee also prepared rowboats, paddles and, making tracks with 850 meters in length." (Head of Competition).

"We registered online by following the requirements set by the committee. The stipulated requirements are an identity card, and proof of registration used for re-registration" (Team Ambarita).

The success of the implementation Solu Bolon 2019 event by looking at the suitability of the data obtained from observations, questionnaires and interviews. Based on the three data collection techniques it can be decided that the process of implementing the event is in accordance with the expected criteria. However, based on observations, it was found that there were still many people who did not know that this event was carried out and the output that would be produced. It can be decided that the lack of socialization and promotion or the public's appeal is still low to enliven this event.

\section{Impact of Event}

At this stage, it will discuss 1) the Solu Bolon event attracts the audience, 2) economic benefits, 3) promotion of the event to the public, 4) increasing the number of visitors. The results of the data that have been obtained from the implementation of the Solu Bolon event can be presented in table 6 as follows: 
Table 6. Impact of Event

\begin{tabular}{ccccc}
\hline Consept & Interesting & $\begin{array}{c}\text { Variabel } \\
\text { Economic } \\
\text { Benefit }\end{array}$ & Promotion & Visitors \\
\hline $\begin{array}{c}\text { Evaluasi } \\
\text { Process } \mathrm{n}=23\end{array}$ & 124 & 217 & 81 & 58 \\
Percentage & 67,39 & 78,62 & 88,04 & 63,04 \\
\hline
\end{tabular}

Based on the table above, it can be seen that the results of research that focus on events that attract people only get a percentage of $67.39 \%$, economic benefits $78.62 \%$, promotion $88.04 \%$ and visitors $63.04 \%$. In addition to the questionnaire data, information was obtained based on observations, namely: the event held was less attractive for the public to see and enliven the competition even though the event was held on the weekend. The committee and the government have carried out promotions through print and online media to expand information to the public. As a result, only residents around Lake Toba participated in watching the competition. To strengthen the observation and questionnaire data, the following interview results were obtained:

"People are less interested in rowing competitions, because they are considered less wellknown than other sports such as football and volleyball. We have made a schedule for the weekend so that people outside Samosir district will also participate in enlivening this event. We also disseminate information by making advertisements and placed in several districts" (Chief Executive).

"We hope that many visitors will come and see this event until the final, but in the implementation it was seen that only the people around Lake Toba acted as spectators on the first day because there were still many participants competing. Even though through this event it is hoped that many visitors will come for a vacation or see the natural beauty of Lake Toba" (Chairman of the Culture, Youth and Sports).

The success of impact of event is only at promotion events because it has become an agenda every year. The committee always advertises through online media and print media so that visitors can increase and the public can get economic benefits. Even though the preparation and implementation that had been planned by the committee was good, there are still some focuses on product evaluation that have not reached the criteria. 


\section{DISCUSSION}

The implementation of Solu Bolon Dragon Boat Race in 2019 event presents four focuses in achieving tourism promotion through sports activities. Based on this results to support the government program which aims to develop the tourism sector to attract local and domestic tourists, the Samosir City government has created the Horas Samosir Fiesta program with one of the Solu Bolon rowboat race agendas. Apart from recreation, the zone between tourism and sport contains a type of activity which is referred to as 'exploratory' (Kotus 2016). The event which was held by the Samosir City Government through the Culture, Youth Sport (Budpora) Office was attended by 21 teams from various regions. The event which started on November 7, 2019 and left 12 teams to enter the final round which was divided into 3 races.

Solu bolon is a way to protect the culture and heritage of the community. This event can further introduce Samosir as a tourist destination that has major events and can increase tourist visits. Maintaining the cleanliness of Lake Toba and always being friendly in welcoming tourists is also an important part of attracting visitors. In addition, the government must provide an information center about the schedule of events, cultural festivals and other activities. Even in the light of low access costs, tend to use new technologies not only to organize their travel, but also to obtain information about a destination, for example, through geo-location based social networks and "augmented reality" which match the mobile communication with information related to specific places and activities (Radicchi 2013). Strong management tools that help physical education, sport medicine, coaching training managers to decide how to improve peak of performance, to maintain the good quality of athletes (Sukarmin and Ndayisenga 2020).

The first day saw many visitors and supporters of the Solu Bolon team competing at Putri Lopian Beach. The committee always improves services and promotions so that every event held can attract visitors from outside the province of North Sumatra. In 2019 the government has carried out online promotions through social media so that there will be many visitors. Local event is an event that is targeted for local audiences and staged primarily for their social, fun and entertainment value. these events often produce a range of benefits, including engendering pride in the community, strengthening a feeling of belonging and creating a sense of place. 
Solu Bolon Dragon Boat Race program, it has been supported by the government by issuing a legal and policy basis to carry out the competition. The District and Provincial Governments always coordinate to develop tourism through sport tourism events. The strategy of sports tourism at the "Banja Vrućica" spa needs to be developed pri-marily as a shift strategy (Milinković et al. 2017). Even though this is a local event, the government's goal has received appreciation from the community to introduce the beauty of Lake Toba to people outside the province of North Sumatera.

The participants' came from the provinces of North Sumatera, Aceh and West Java. In 2019 there was an increase in the number of participants so that it can be said that the committee was successful in promoting through print and online media. The use of promotion through social media also affects the development of information dissemination to participants from outside the province. It is necessary to develop destination-specific marketing strategies for upland sport destinations (Hodeck and Hovemann 2015). The establishment of an organization should be accomplished so that the various sectors engaging in sport tourism will be coordinated and so that the country's projection abroad will be thorough, and thus the selection of the country as a destination will not be hindered due to lack of information (Yiannakis 2010).

The government also supports the financing of each event which aims to advance the tourist area so that it has economic benefits for the residents around Lake Toba. Residents see sports as one of the factors contributing to the identity of the municipality, underlying motivations for participation as the search for happiness, health, wellbeing, fun and, effects in the local economy (Perna, Custódio, and Oliveira 2019). Nature and culture characterize every region in Indonesia as a legacy that must be preserved. Segmentation of the tourists and a strategy for tourism destinations that highlight culture, endemic forest, authentic landscapes and the hospitality of local people in active tourism services (Soares and Nunes 2020).

The committee also establishes competition rules as the basis for implementing the event so that there are no problems. The committee also prepared rowboat and paddle equipment because this competition was one of the characteristics of elite vehicles in ancient times. The race schedule for 3 days did not attract the public to watch the competition, only on the first day many residents came while on the second and third days the audience began to 
decline. As a result, after this event was completed the number of visitors to Lake Toba had not increased significantly.

This paper discusses the management event of Solu Bolon Dragon Boat event as a sport tourism program in the province of North Sumatera, exactly on Lake Toba. This lake is the largest lake in Southeast Asia because it has a length of 87 kilometers, a width of 27 kilometers and an altitude of 904 meters above sea level. This place is often visited by tourists because it is famous for its natural beauty. Therefore, the government wants to develop a sport tourism event in Lake Toba so that it can have an impact on the surrounding community.

The main focus of this paper is to evaluate the Solun Bolon event which aims to promote Lake Toba tourism so that it has economic benefits and increases visitors. Affect the local economy and can make the surrounding communities and schools around Lake Sipin affected (Nugraha et al. 2020). In the evaluation framework, the following results have been obtained: context evaluation shows good criteria because it has a legal and policy basis for organizing events. Input evaluation: the government has the resources to support each event that is incorporated in the Horas Samosir Fiesta so that it shows good criteria. Process evaluation shows good criteria because the committee has determined the rules for participants and the implementation of competition. In the product evaluation, set results have not met the target because this event has not been able to attract many people, the number of post-event visitors has not increased even though the government has carried out promotions through social and electronic media.

\section{CONCLUSION}

So that this event only provides economic benefits at the time of the competition. Conclusion at the Solu Bolon promotion event which is carried out through social and electronic media can expand information so that there is an increase in the number of participants, even though the audience who comes is only local residents, but with many participants it can increase economic benefits for the community.

\section{REFERENCES}

An, Bang, Munehiko Harada, and Shintaro Sato. 2020. "Service Quality, Satisfaction, and Behavioral Intention in a Triathlon Event: The Different Experiences between Local and Non-Local Participants." Journal of Sport and Tourism 24(2):127-42. 
Anon. 2016. "The Contribution Of Sports Event To The Income Level Of Locals Around." Active: Journal of Physical Education, Sport, Health and Recreation.

Buning, Richard J. 2019. “Sport Tourism Development.” Journal of Sport \& Tourism.

Coll Ramis, Miquel Angel. 2020. "Tourism Education in Spain's Secondary Schools: The Curriculums' Perspective.” Journal of Hospitality, Leisure, Sport and Tourism Education.

Cooper, J. A. 2020. "Making Orange Green? A Critical Carbon Footprinting of Tennessee Football Gameday Tourism." Journal of Sport and Tourism 24(1):31-51.

Downward, Paul, Simona Rasciute, and Cristina Muniz. 2020. "Exploring the Contribution of Activity Sports Tourism to Same-Day Visit Expenditure and Duration." Journal of Sport and Tourism 24(2):111-26.

Fadda, Nicoletta. 2020. "Entrepreneurial Behaviours and Managerial Approach of Lifestyle Entrepreneurs in Surf Tourism: An Exploratory Study." Journal of Sport and Tourism 24(1):53-77.

Gibson, Heather J., Kyriaki Kaplanidou, and Sung Jin Kang. 2012. "Small-Scale Event Sport Tourism: A Case Study in Sustainable Tourism.” Sport Management Review.

Happ, Elisabeth, Martin Schnitzer, and Mike Peters. 2021. "Sport-Specific Factors Affecting Location Decisions in Business to Business Sport Manufacturing Companies: A Qualitative Study in the Alps." International Journal of Sport Management and Marketing 21(1/2):21.

Hemmonsbey, Janice, and Tembi Maloney Tichaawa. 2020. "Brand Messages That Influence the Sport Tourism Experience: The Case of South Africa." Journal of Sport and Tourism 24(3):177-94.

Hodeck, Alexander, and Gregor Hovemann. 2015. "Destination Choice In German Winter Sport Tourism: Empirical Findings.” Polish Journal of Sport and Tourism 22(2):114-17.

Ivanov, Stanislav H., and Craig Webster. 2013. "Tourism's Contribution to Economic Growth: A Global Analysis for the First Decade of the Millennium." Tourism Economics.

Kemenpar. 2016. "Pembangunan Destinasi Pariwisata Prioritas 2016 - 2019." Rapat Koordinasi Nasional Kementerian Pariwisata "Akselerasi Pembangunan Kepariwisataan Dalam Rangka Pencapaian Target 12 Juta Wisman Dan 260 Juta Wisnus 2016."

Kim, Wonyoung, Ho Mun Jun, Matthew Walker, and Dan Drane. 2015. "Evaluating the Perceived Social Impacts of Hosting Large-Scale Sport Tourism Events: SCALE Development and Validation." Tourism Management. 
Kotus, Jacek. 2016. "Relations between Tourism and Sport in the Context of Tourism as an Academic Discipline." Turyzm 26(1):19-25.

Masjhoer, Jussac Maulana, and Dyah Wahyuning Tyas. 2020. "Model Pengembangan International Musi Triboatton Sebagai Atraksi Sport Tourism." Jurnal Pariwisata Terapan.

Milinković, Zoran, Slobodan Simović, Adriana Ljubojević, Jelena Jovanović, and Kristina Pantelić Babić. 2017. "Strategic Analysis of the External and Internal Environment of Sport Tourism at the 'Banja Vrućica' Spa." Polish Journal of Sport and Tourism 24(4):252-58.

Nugraha, Ugi, Moch Asmawi, Hidayat Humaid, and Firmansyah Dlis. 2020. "Sports Teacher Perception about Lake Sipin Sport Tourism Area in Jambi City." International Journal of Human Movement and Sports Sciences 8(4):103-9.

Perna, Fernando, Maria João Custódio, and Vanessa Oliveira. 2019. "Local Communities and Sport Activities Expenditures and Image: Residents' Role in Sustainable Tourism and Recreation." European Journal of Tourism, Hospitality and Recreation 9(1):49-59.

Radicchi, Elena. 2013. "Tourism and Sport: Strategic Synergies to Enhance the Sustainable Development of a Local Context." Physical Culture and Sport. Studies and Research 57(1):44-57.

Soares, Jorge, and Naidea Nunes. 2020. “Levada Walks and Canyoning as Mountain Sport Products in Nature Tourism ." European Journal of Tourism, Hospitality and Recreation 10(1):41-55.

Sukarmin, Yustinus, and Japhet Ndayisenga. 2020. "Evaluation of Burundi Physical Education Teachers, Coaches, and Athletes' Sport Nutrition, Massage, and Physiotherapeutic Exercises Knowledge." International Journal of Human Movement and Sports Sciences 8(4):154-59.

Yamashita, Rei, and Kosuke Takata. 2020. "Relationship between Prior Knowledge, Destination Reputation, and Loyalty among Sport Tourists." Journal of Sport and Tourism 24(2):143-53.

Yiannakis, Orphanos. 2010. "Past, Present and Future Perspective of Sport Tourism in Cyprus." Physical Culture and Sport. Studies and Research 46(1):268-75. 